\title{
Screening of yarrow (Achillea millefolium Agg.) populations in Serbia for yield components and essential oil composition
}

\author{
Dejan Pljevljakušić ${ }^{1,}$, Mihailo Ristić $^{1}$, And Katarina Šavikin ${ }^{1}$ \\ ${ }^{1}$ Institute for Medicinal Plants Research "Dr. Josif Pančić", Belgrade, Serbia \\ *Corresponding author:dpljevljakusic@mocbilja.rs
}

Received: November 23, 2017

Accepted: December 14, 2017

Published on-line: December 16, 2017

Published: December 25

\begin{abstract}
Yarrow (Achillea millefolium Agg.) is well-known medicinal plant, with a wide spectrum of applications and it is one of the most frequently used plant drug in Serbia. In this study, we have observed cultivation and essential oil chemical properties of $28 \mathrm{~A}$. millefolium populations collected from Serbian sites. In the second vegetation, the yield of useful part (upper $15 \mathrm{~cm}$ ) ranged from $925-3630$ $\mathrm{kg} / \mathrm{ha}$, while the yield of essential oil ranged from $0.40-0.82 \%$. The most dominant compounds in monoterpene fraction were $\beta$-pinene (max. 36.3\%), sabinene (max. 35.7\%), 1,8-cineol (max. 26.6\%) and borneol (max. 20.2\%), while in the sesquiterpene fraction the most abundant compounds were trans-caryophyllene (max. 18.6\%) and lavandulyl acetate (max. 18.1\%). Among aromatic compounds, the most abundant was chamazulene (max. $29.1 \%$ ). This screening has shown that only 10 populations out of 28 satisfied official quality requirement of $0.02 \%$ of chamazulene in the dried drug. Four populations had higher yield than commercial variety ProA, while one of them had even higher level of chamazulene.
\end{abstract}

Key words: Achillea millefolium, essential oil, chemistry, GC, GC-MS, yield

\section{INTRODUCTION}

Genus Achillea includes about 120 perennial species, which are mostly present in Euro-Asian region. Plants from this genus are, in wide diversity, spread in Serbian territory, where 19 species have been recognized (Gajić, 1975). Regarding pharmacological properties, the most important species belong to the Millefolium group, which is characterized by wide morphological, cytological and chemical diversity, and it has been botanically systemized in few subspecies whose chromosome numbers are ranging from diploid $(2 \mathrm{n}=18)$ to octaploid $(8 \mathrm{n}=$ 72) forms (Nemeth, 2005). Therefore A. millefolium L. sensu lato is the developing evolutionary taxon currently considered as an aggregate of 12 species (Saukel and Langer, 1992). Since this group consists of several species difficult to distinguish which again are polymorphic, the raw material from wild collecting often represents a mixture of several species. According to European Pharmacopoeia (Ph.Eur.8.0., 2013), the main quality parameter is the essential oil content (minimum $2 \mathrm{ml} / \mathrm{kg}$ ), with not less than $0.02 \%$ of proazulenes, expressed as chamazulene. Diploid species (A. asplenifolia Vent. and $A$. setacea Waldst. et Kit.) and tetraploid species (A. collina Becker ex Reichenb.) are considered pharmaceutically acceptable, while hexaploid species (A. millefolium L. sensu stricto and $A$. distans Waldst. et Kit. and octaploid species (A. pannonica Scheele.) are considered as chamazulene-free and therefore should be avoided (Chandler et al., 1982).

Yarrow (Achillea millefolium Agg.) is well-known medicinal plant, with a wide spectrum of applications. It is one of the most frequently used plant drug in Serbia (Tucakov, 1984). Upper parts of the plant collected during the blooming are recognized as an anti-inflammatory, antinociceptive, spasmolytic, antimicrobial and holagog drug (Nadim et al., 2011; Cavalcanti et al., 2006; Benedek et al., 2008; Ali et al., 2017). Yarrow preparations in the form of infusions, decoctions or fresh juices have been applied against various indications such as anorexia, stomach cramps, flatulence, gastritis, enteritis, internal and external bleeding (Willuhn, 2002; Wichtl, 2004).

In this study, we have observed cultivation and chemical properties of 28 A. millefolium populations collected from Serbian sites. The main objective of this research was to evaluate local yarrow populations for yield components and chemical constituents of the essential oil regardless their explicit botanical taxonomy. Furthermore, we tried to explore what would be the yield and quality of only upper $15 \mathrm{~cm}$ of plant considering that this part represents "flowering tops" as it is suggested by official quality standard (Ph.Eur.8.0., 2013). 
Table 1. The origin of yarrow (A. millefolium Agg.) populations

\begin{tabular}{|c|c|c|c|c|c|}
\hline Population & Locality & Latitude & & Longitude & Altitude $[\mathrm{m}]$ \\
\hline 1 & Sokobanja - Ozren & $43^{\circ} 38^{\prime} 13.12^{\prime \prime}$ & $\mathrm{N}$ & $21^{\circ} 52^{\prime} 27.02^{\prime \prime} \mathrm{E}$ & 472 \\
\hline 3 & Sokobanja - Ripaljka & $43^{\circ} 38^{\prime} 01.69^{\prime \prime}$ & $\mathrm{N}$ & $21^{\circ} 52^{\prime} 51.20^{\prime \prime} \quad \mathrm{E}$ & 573 \\
\hline 4 & Sokobanja - Očno & $43^{\circ} 37^{\prime} 52.92^{\prime \prime}$ & $\mathrm{N}$ & $21^{\circ} 52^{\prime} 22.19^{\prime \prime} \mathrm{E}$ & 634 \\
\hline 5 & Sokobanja - Moravica & $43^{\circ} 38^{\prime} 38.80^{\prime \prime}$ & $\mathrm{N}$ & $21^{\circ} 53^{\prime} 01.55^{\prime \prime} \mathrm{E}$ & 330 \\
\hline 8 & Sokobanja - Bovan lake & $43^{\circ} 39^{\prime} 36.44^{\prime \prime}$ & $\mathrm{N}$ & $21^{\circ} 48^{\prime} 16.44^{\prime \prime} \mathrm{E}$ & 266 \\
\hline 11 & Aleksinac & $43^{\circ} 33^{\prime} 08.53^{\prime \prime}$ & $\mathrm{N}$ & $21^{\circ} 42^{\prime} 17.98^{\prime \prime} \mathrm{E}$ & 218 \\
\hline 12 & Aleksinac - Žitkovac & $43^{\circ} 31^{\prime} 09.14^{\prime \prime}$ & $\mathrm{N}$ & $21^{\circ} 41^{\prime} 28.71^{\prime \prime} \mathrm{E}$ & 161 \\
\hline 13 & Ražanj - Deligrad & $43^{\circ} 39^{\prime} 47.48^{\prime \prime}$ & $\mathrm{N}$ & $21^{\circ} 32^{\prime} 58.65^{\prime \prime} \quad \mathrm{E}$ & 250 \\
\hline 14 & Busilovac & $43^{\circ} 47^{\prime} 57.09^{\prime \prime}$ & $\mathrm{N}$ & $21^{\circ} 26^{\prime} 01.60^{\prime \prime} \quad \bar{E}$ & 150 \\
\hline 15 & Ćuprija & $43^{\circ} 57^{\prime} 04.93^{\prime \prime}$ & $\mathrm{N}$ & $21^{\circ} 22^{\prime} 13.22^{\prime \prime} \quad \mathrm{E}$ & 116 \\
\hline 16 & Vojska & $44^{\circ} 03^{\prime} 48.88^{\prime \prime}$ & $\mathrm{N}$ & $21^{\circ} 12^{\prime} 09.15^{\prime \prime} \mathrm{E}$ & 119 \\
\hline 18 & Velika Plana & $44^{\circ} 22^{\prime} 55.25^{\prime \prime}$ & $\mathrm{N}$ & $21^{\circ} 04^{\prime} 12.76^{\prime \prime} \mathrm{E}$ & 102 \\
\hline 19 & Begaljica & $44^{\circ} 38^{\prime} 11.94^{\prime \prime}$ & $\mathrm{N}$ & $20^{\circ} 38^{\prime} 14.82^{\prime \prime} \mathrm{E}$ & 255 \\
\hline 20 & Padej & $45^{\circ} 49^{\prime} 00.15^{\prime \prime}$ & $\mathrm{N}$ & $20^{\circ} 09^{\prime} 51.96^{\prime \prime} \quad \mathrm{E}$ & 72 \\
\hline 23 & Ravna Gora - monument & $44^{\circ} 06^{\prime} 31.15^{\prime \prime}$ & $\mathrm{N}$ & $20^{\circ} 09^{\prime} 21.19^{\prime \prime} \mathrm{E}$ & 731 \\
\hline 24 & Topli Do - Mijina pojata & $43^{\circ} 20^{\prime} 25.55^{\prime \prime}$ & $\mathrm{N}$ & $22^{\circ} 42^{\prime} 31.44^{\prime \prime} \quad \mathrm{E}$ & 833 \\
\hline 25 & Dobro polje & $43^{\circ} 53^{\prime} 32.00^{\prime \prime}$ & $\mathrm{N}$ & $19^{\circ} 29^{\prime} 55.00^{\prime \prime} \mathrm{E}$ & 1140 \\
\hline 26 & Divčibare - viewpoint & $44^{\circ} 05^{\prime} 48.18^{\prime \prime}$ & $\mathrm{N}$ & $19^{\circ} 58^{\prime} 12.64^{\prime \prime} \mathrm{E}$ & 1012 \\
\hline 27 & Maljen & $44^{\circ} 06^{\prime} 59.45^{\prime \prime}$ & $\mathrm{N}$ & $20^{\circ} 03^{\prime} 45.63^{\prime \prime} \mathrm{E}$ & 898 \\
\hline 28 & Rajac (top) & $44^{\circ} 08^{\prime} 17.65^{\prime \prime}$ & $\mathrm{N}$ & $20^{\circ} 13^{\prime} 18.06^{\prime \prime} \mathrm{E}$ & 840 \\
\hline 29 & Medvednik & $44^{\circ} 12^{\prime} 44.00^{\prime \prime}$ & $\mathrm{N}$ & $19^{\circ} 40^{\prime} 50.00^{\prime \prime} \mathrm{E}$ & 834 \\
\hline 30 & Rajac - Dobre Vode & $44^{\circ} 08^{\prime} 10.00^{\prime \prime}$ & $\mathrm{N}$ & $20^{\circ} 11^{\prime} 10.00^{\prime \prime} \mathrm{E}$ & 620 \\
\hline 31 & Suvobor - Vučje trkalište & $44^{\circ} 07^{\prime} 11.38^{\prime \prime}$ & $\mathrm{N}$ & $20^{\circ} 11^{\prime} 38.38^{\prime \prime} \quad \mathrm{E}$ & 710 \\
\hline 32 & Divčibare - Kraljev sto & $44^{\circ} 07^{\prime} 20.00^{\prime \prime}$ & $\mathrm{N}$ & $20^{\circ} 01^{\prime} 45.00^{\prime \prime} \quad \mathrm{E}$ & 1030 \\
\hline 35 & Ovča - Rugby field & $44^{\circ} 53^{\prime} 00.39^{\prime \prime}$ & $\mathrm{N}$ & $20^{\circ} 28^{\prime} 50.90^{\prime \prime} \mathrm{E}$ & 69 \\
\hline 36 & Hohenheim $1^{\mathrm{a}}$ & & & & \\
\hline 38 & Hohenheim $2^{\mathrm{a}}$ & & & & \\
\hline 39 & $\operatorname{ProA}^{\mathrm{b}}$ & & & & \\
\hline
\end{tabular}

a Botanical garden seed exchange, Hohenheimer Gärten

${ }^{\mathrm{b}}$ Commercial variety, Pharmaplant $\mathrm{GmbH}$, Germany

\section{MATERIALS AND METHODS}

\section{Plant material}

\subsection{Population origin}

Seeds of 35 local yarrow populations were collected during the August 2004 (1-35). Each collecting site was at least 5 $\mathrm{km}$ distant (air distance) from the nearest one. Additionally, seeds of three populations (36-38) were purchased from seed exchange programme (Hohenheimer Gärten) and one commercial variety (ProA, Pharmaplant) has been included (39). All collected populations were sown in the glass-house for seedlings production, but only 28 among them had seeds viable enough to form a sufficient number of seedlings to be included in field cultivation experiment. Details of included populations are listed in Table 1.

\subsection{Field trial}

Field trial has been conducted on April 20 $0^{\text {th }}, 2005$ at Pančevo (South Banat, Serbia). Soil type was Calcic Gleysol (pH 6.8) at altitude $81 \mathrm{~m}$. Average rainfall for 2005 and 2006 was 560 $\mathrm{mm}$ and $620 \mathrm{~mm}$, respectively, while min-max vegetation (Mar-Sep.) temperatures were $7-33^{\circ} \mathrm{C}$ and $5-32^{\circ} \mathrm{C}$, respectively. The experimental design was completely randomized design where each population has been represented with 40 plants separated in four repetitions. Planting scheme was $70 \times 50 \mathrm{~cm}$ representing approximate plant density of 20000 plants / ha All plants were in the rosette phenophase during the first year of the trial. Samples for yield quality estimation has been taken from flowering plants during June and July 2006. Plants were harvested to the ground level for the purpose of yield components estimation. Harvested plants have been tied in bundles and dried in shade. Dried plants were measured for total yield (whole plant), useful part yield (upper $15 \mathrm{~cm}$ of the plant). Useful part of the plant has been separated with manual steel sheet cutter. Count of flowering stems and plant height were also recorded on dried plants, while width of plant habitus was measured in situ. Useful part of plants has been considered as main cultivation property of populations. Since yarrow plants are very polymorphic, each measurement has been done in ten replications.

Collected samples from field trial were determined and clas- sified taxonomically as A. millefolium Agg. by Prof. Dr. Zora Dajić Stevanović. Voucher specimens have been deposited at the Herbarium of Institute for medicinal plants research „Dr. Josif Pančić", Belgrade, Serbia.

\section{Gas chromatography and Mass spectroscopy}

\subsection{Essential oil extraction}

The air-dried yarrow plants (useful parts) were grounded, and the volatile oils were obtained by hydrodistillation using a Clevenger-type apparatus according to Procedure I of the Yugoslav Pharmacopoeia IV (Ph.Jug.IV, 1951). The essential oil yield, expressed as a percentage, was calculated on a moisturefree basis. Samples $(20 \mu \mathrm{L})$ were dissolved in $\mathrm{EtOH} 96 \%(2 \mathrm{~mL})$ and kept in the refrigerator until further analysis. A single plant from population 31 was morphologically very distinct from rest of the population. Thus, that plant was analyzed separately and marked as 31a.

\subsection{GC-FID analysis}

The GC-FID analyses were carried out with HP-5890 Series II apparatus (Hewlett-Packard, Waldbronn, Germany) equipped with a split-splitless injector, a flame-ionization detector (FID), and HP- 5 capillary column $(25 \mathrm{~m} \times 0.32 \mathrm{~mm}$ i.d., film thickness $0.52 \mu \mathrm{m})$. The oven temperature was programmed rising from 40 to $260^{\circ} \mathrm{C}$ at $4^{\circ} \mathrm{C} / \mathrm{min}$; injector temperature $250^{\circ} \mathrm{C}$; detector temperature $300^{\circ} \mathrm{C}$; carrier gas, $\mathrm{H}_{2}(1.0 \mathrm{~mL} / \mathrm{min})$. Samples were injected in the amount of $1 \mu \mathrm{L}$. Split ratio was 1:5. The relative contents expressed as percentages were obtained from electronic integration of the peak areas measured using FID.

\subsection{GC/MS analysis}

The GC/MS analyses were performed under almost the same analytical conditions as the GC-FID analyses, with HP G 1800C Series II GCD analytical system (Hewlett-Packard, Palo Alto, CA, USA) equipped with HP-5MS capillary column (30 $\mathrm{m} \times 0.25 \mathrm{~mm}$ i.d., film thickness $0.25 \mu \mathrm{m})$. Helium $(1.0$ $\mathrm{mL} / \mathrm{min}$ ) was used as carrier gas, and the transfer-line temperature (MSD) was heated to $260^{\circ} \mathrm{C}$. Mass spectra were acquired in the EI mode $(70 \mathrm{eV})$ over the $\mathrm{m} / \mathrm{z}$ range $40-450 \mathrm{amu}$. Samples $(1 \mu \mathrm{L})$ were injected in split mode (1:30). The identification of 


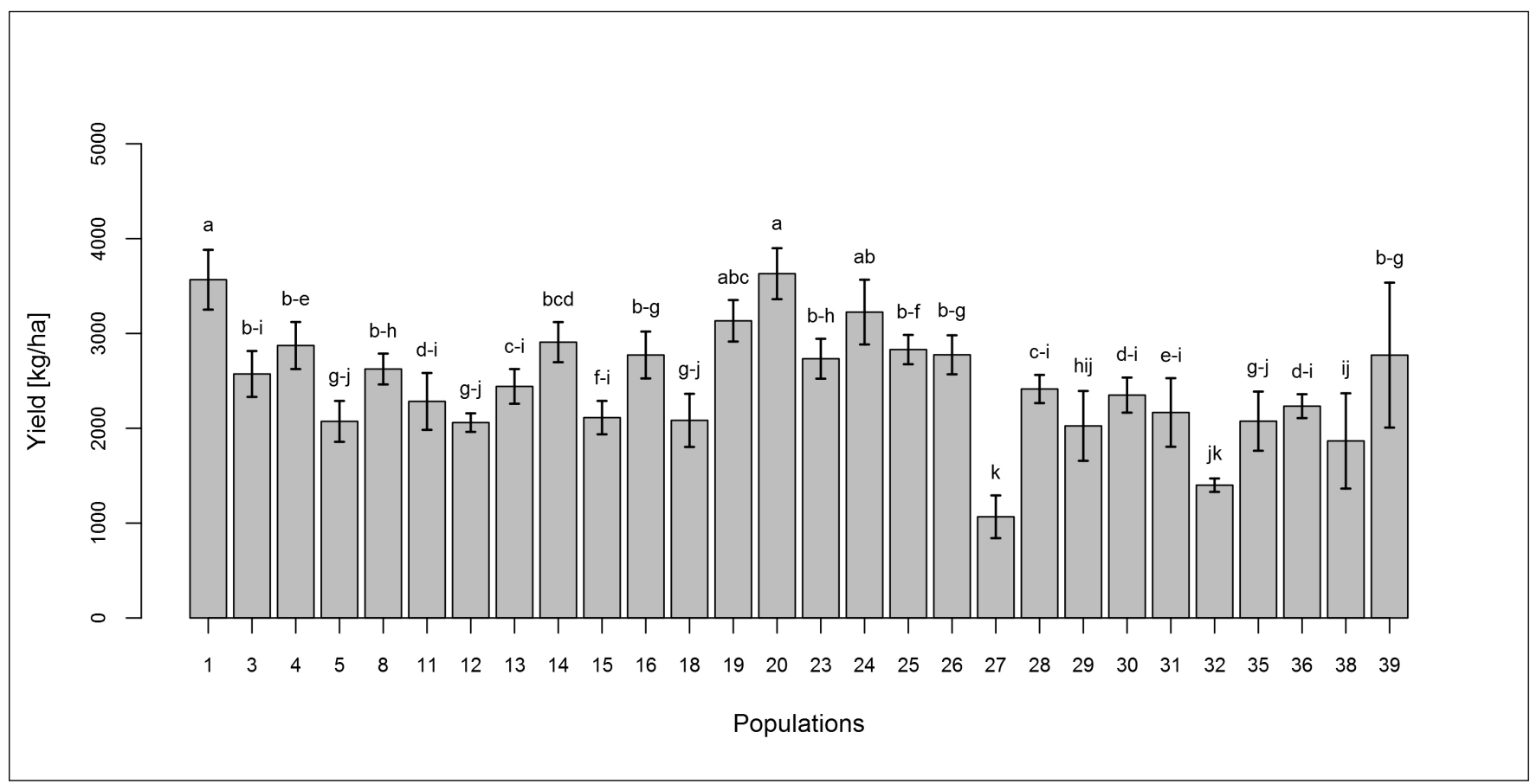

Fig. 1. Yields of cultivated yarrow populations (upper $15 \mathrm{~cm}$ of the plant).

the constituents was performed by comparing their mass spectra and retention indices (RIs) with those obtained from authentic samples and/or listed in the NIST/Wiley mass-spectra libraries, using different types of search (PBM/NIST/AMDIS) and available literature data (Hochmuth, 2006; Adams, 2007).

\section{Statistical analysis}

Since measurements of a large number of replications in agronomical assay produced data with very wide variance in populations, estimation of differences between groups was inaccessible. Therefore for each population quantile reduction of data has been applied, where only second and third quartiles have been taken for further statistical analysis. The hypothesis that all populations yield useful parts equally has been evaluated with one-way ANOVA and differences among mean values has been tested with post-hoc Duncan's multiple range test. Production differences among populations have been presented graphically (bar plot with standard deviations). The strength of yield components relationships has been estimated through Pearson's correlation coefficients. Essential oil compositions of observed populations have been presented in the table, while their similarity has been accessed through cluster analysis with Euclidian single linkage distance and presented graphically as an unrooted dendrogram. All statistical computing and graphs production was made by $\mathrm{R}$ software packages (The R Project for Statistical Computing).

\section{RESULTS AND DISCUSSION}

\section{Yield components}

In the second vegetation, yarrow populations' yield ranged from $925-3630 \mathrm{~kg} / \mathrm{ha}$ (Figure 1). Our findings differ from previously published papers most probably because we have observed yields of only upper $15 \mathrm{~cm}$ of the plants. Giorgi et al. (2005) reported yield in range of 5-12 $t / h a$, while Dachler and Pelzmann (1999) reported ca. $4.5 \mathrm{t} / \mathrm{ha}$. Since these papers lack in cutting height information, we believe that discrepancies in reported yields and the yield range of our research is result of our intention to estimate dry mass of the "flowering tops". Population 20 had the highest yield, while population 27 had the smallest, $3630 \mathrm{~kg} / \mathrm{ha}$ and $925 \mathrm{~kg} / \mathrm{ha}$, respectively. Most

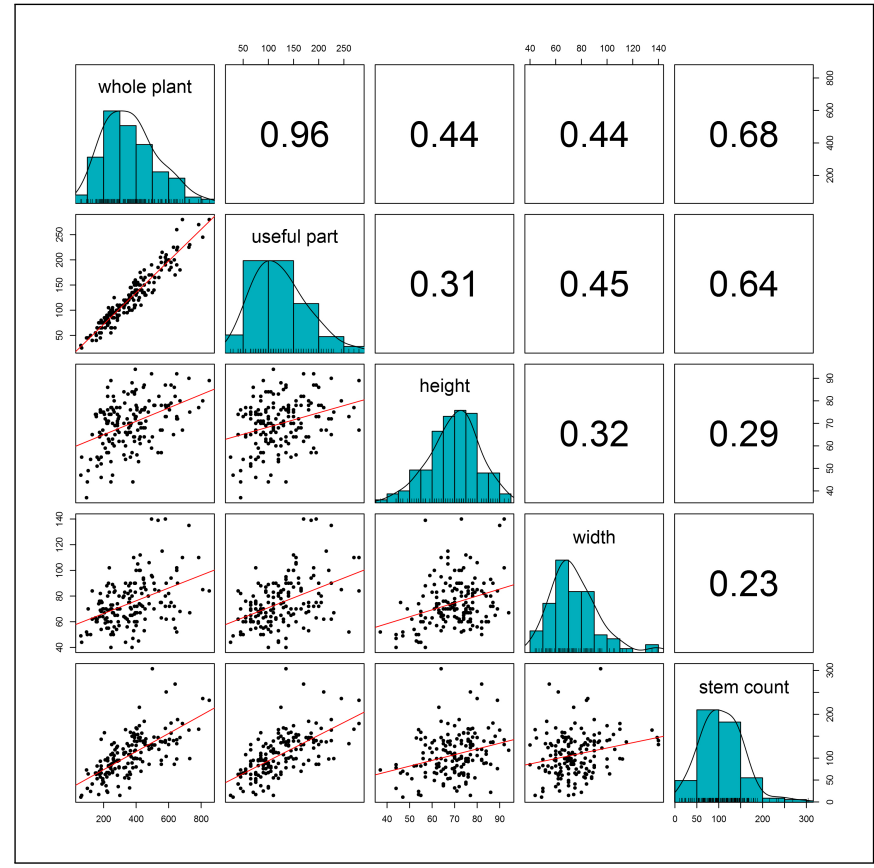

Fig. 2. Correlation coefficients among yield components of A. millefolium Agg. populations.

of the populations, accurately 25 of them, yielded more than $2000 \mathrm{~kg} / \mathrm{ha}$. Populations 1, 19, 20 and 25 showed the highest yield potential and no statistically significant differences among their mean values has been observed. The smallest yield potential has been recorded in populations 27 and 32 . Yield components have been observed through correlation matrix (Figure 2). Whole plant yield ranged from $20-300$ $\mathrm{g} /$ plant and showed the strongest correlation to useful part yield $(r=0.96)$. This was expected since robustness of the whole plant was inherited by the useful part of the plant trait. In other words useful part of the plant was only the part of the whole plant with exactly the same number of stems, which is strongly correlated with both traits $(\mathrm{r}=0.64$ and $\mathrm{r}=0.68$, respectively). On the other hand, plant height and width traits 
showed weaker correlation to the useful part of the plant ( $\mathrm{r}$ $=0.31$ and $\mathrm{r}=0.45$, respectively). This is observations clearly showed that only number of stems, among morphological traits, contributes to useful part yield.

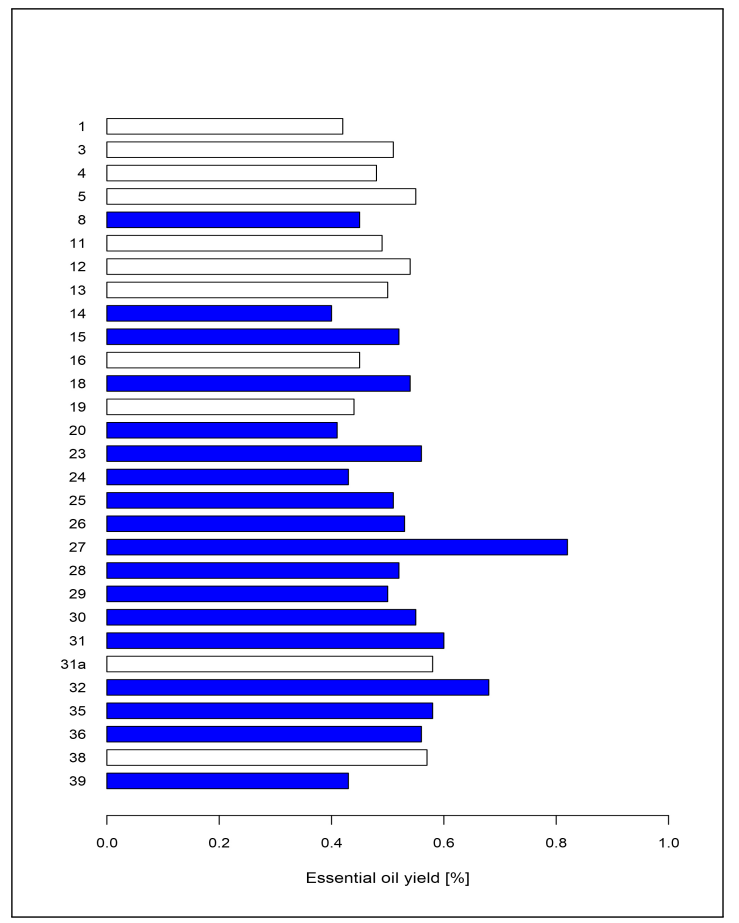

Fig. 3. Essential oil yield of cultivated yarrow populations (upper $15 \mathrm{~cm}$ of the plant); white bars represent chamazulene-free populations.

\section{Essential oil yield}

The yield of essential oil of the cultivated yarrow populations in our experiment ranged from $0.40-0.82 \%$ (Figure 3 ). Chamazulene-free populations have been represented in the figure with white bars. Total count of chamazulene-free populations was 11 and at this level we can distinguish which population is not suitable for pharmaceutical purposes according to official standards (Ph.Eur.8.0., 2013). The highest oil yield was observed in population $27(0.82 \%)$, while the lowest yield was recorded in population $14(0.40 \%)$. Majority of oil yield ( $59 \%$ of populations) have been observed in amounts more than $0.5 \%$. These data are accordance than previously reported, where yarrow oil yield ranged from 0.11 to $1.03 \%$ (Verma et al., 2017; Spinarova and Petrikova, 2003; Raal et al., 2012; Ghasemi Pirbalouti, 2017). Dachler and Pelzmann (1999) reported yarrow yields up to $0.5 \%$. According to mean values of reported yields, oil content in our samples was above average. Again, this is most probably the result of plant cutting height in our experiment.

\section{Essential oil composition}

Chromatogram integration of yarrow essential oils recognized 113 components out of which we were able to identify 96 (Table 2). One of these identifications was tentative $(R I=1679.4)$. In all samples number of total compounds varied from 45 to 74. Compositions of essential oils were very diverse, but in general the most dominant compounds in monoterpene fraction were $\beta$-pinene (max. $36.3 \%$ ) and sabinene (max. 35.7\%), followed by 1,8-cineol ( $\max .26 .6 \%$ ), borneol (max. $20.2 \%$ ), trans- $\beta$-ocimene (max. $16.1 \%$ ), camphor (max. $11.3 \%$ ), cischrysanthemol (max. $11.3 \%$ ) and trans-verbenol (max. 10.1\%). In the sesquiterpene fraction the most abundant compounds were , trans-caryophyllene (max. $18.6 \%$ ) and lavandulyl acetate $(\max .18 .1 \%)$, followed by elemol (max. $15.5 \%), \alpha-$ bisabolol (max. 14.9\%), terpinen-4-ol (max. 12.9\%). Among aromatic compounds, the most abundant was chamazulene (max. 29.1\%).

Our results are in accordance with previously reported chemical compositions of yarrow essential oils. Shawl et al. (2002) reported camphor $(28 \%), 1,8$-cineole $(12 \%)$, germacrene-D $(12 \%)$ and cischrysanthenyl acetate $(8 \%)$ as the major components of essential oils of A. millefolium from Iran. Furthermore, Mockute and Judzentiene (2003) partially confirmed our findings with reporting chamazulene (max. 23.2\%), $\beta$ pinene (max. 26.5\%), borneol (max. 13.2\%) and camphor (max. $13.1 \%$ ), but also with addition of trans-nerolidol (max. 13.5\%), which has been found in our samples in very low amount (0.1-0.9\%). Camphor was identified as main component in amount of about $40 \%$ in $A$. sieheana and A. clavennae, while borneol was most abundant compound in A. holosericea (Tabanca et al., 2004; Stojanović et al., 2005). The high amount of 1,8-cineole (34.2\%) has been reported A. eriophora (Weyerstahl et al., 1997). The high amount of sabinene, as we found in our populations 36, 38 and 39 (19.3-35.7\%), has been also previously reported(Verma et al., 2017; Nadim et al., 2011; Conti et al., 2010; Boskovic et al., 2005).

Serbian populations were lower in sabinene content, while introduced populations (Hohenheimer Gärten and commercial variety ProA) had very high content. One morphologically different plant from population 31, which was separately analyzed, gave completely different chemical profile than the population from which it has been drawn (sample 31a). Furthermore, this plant was chamazulene-free, while chamazulene has been identified in a population sample. Regarding chamazulene content, among all analyzed populations only 10 of them satisfied official quality requirement of $0.02 \%$ of chamazulene in dried drug (Ph.Eur.8.0., 2013). These populations were $20,23,24,26,27,29,31,32,36$ and 39 . The level of chamazulene in these populations ranged from $0.02 \%$ (pop. 31) to $0.24 \%$ (pop. 27).

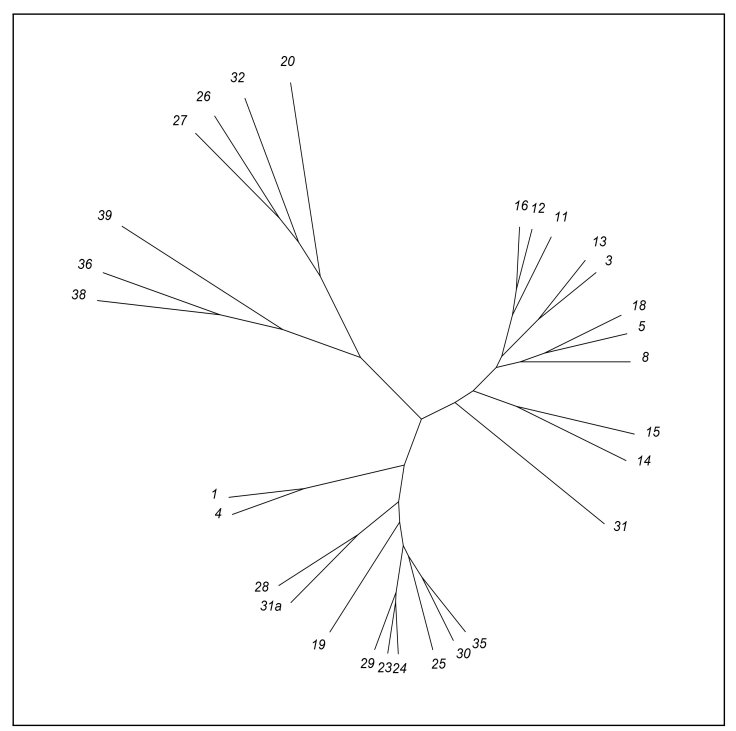

Fig. 4. Cluster analysis based on chemical composition of yarrow essential oils. 
Table 2. Essential oil profiles of Achillea millefolium populations

Populations

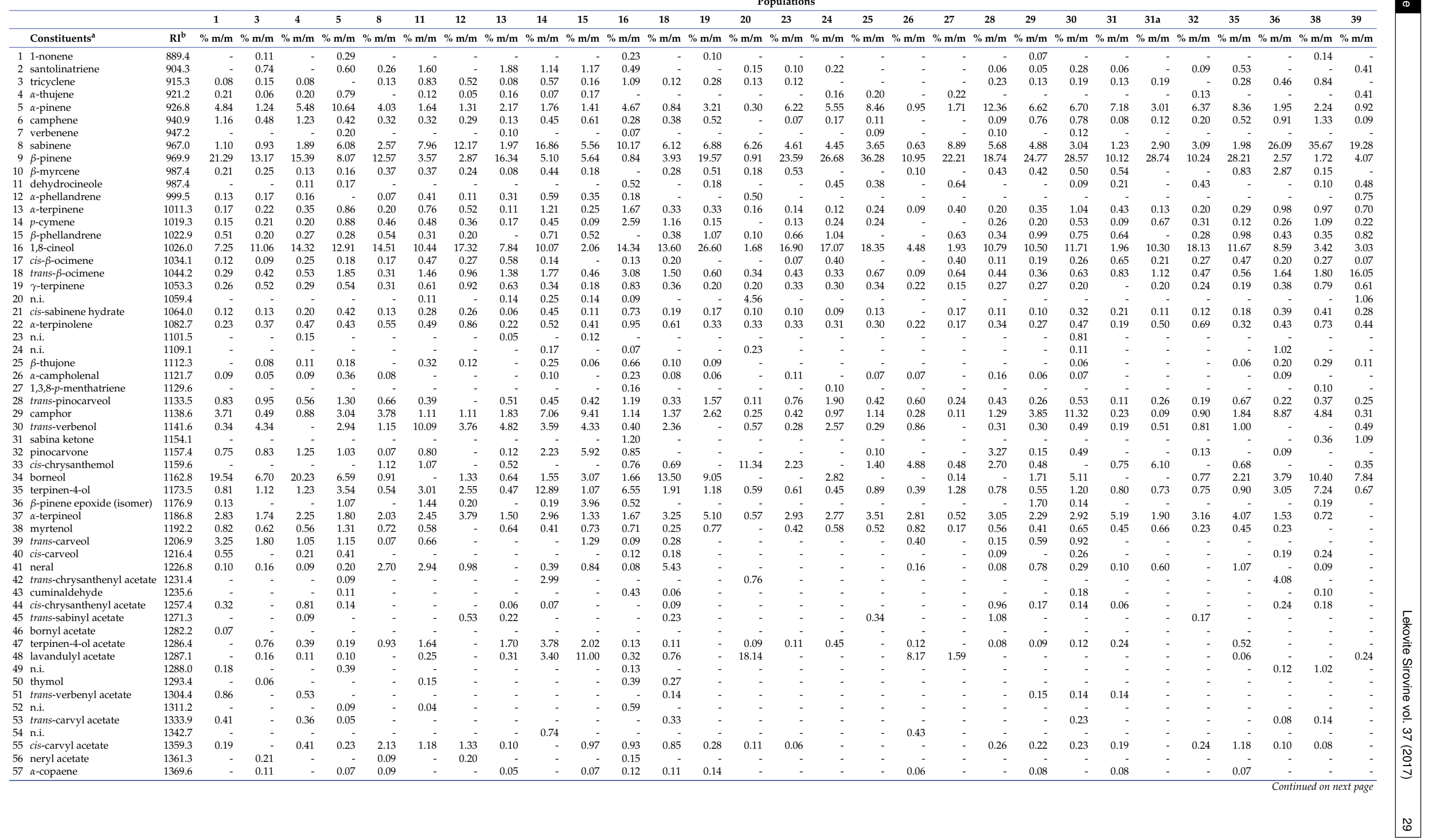


Cluster analysis of yarrow essential oil chemical profiles in our experiment revealed branching showed on unrooted dendrogram in Figure 4. Population grouping based on single linkage Euclidian distances has distinguished sub-branch with populations rich in chamazulene (18.3-29.1\% of essential oil or over $0.09 \%$ in the dry drug). Those populations are 20, 26, 27 and 32 , and all of them could be included in the future selection process. On the same branch, sabinene rich populations (pop. 38, 36 and 39) formed sub-branch. Commercial variety ProA (pop. 39) has been grouped on the same branch with chamazulene rich populations, but thanks to its high level of sabinene (19.3\%) it has been grouped in sub-branch with sabinene rich populations.

\section{CONCLUSION}

Screening of yarrow populations in Serbia revealed valuable information regarding yield of raw material and quality of the essential oil. The yield has been observed in the range of $925-3630 \mathrm{~kg} / \mathrm{ha}$, while essential oil content ranged from $0.40-0.82 \%$. The most dominant compounds in monoterpene fraction were $\beta$-pinene ( $\max .36 .3 \%$ ), sabinene (max. $35.7 \%$ ), 1,8-cineol (max. 26.6\%) and borneol (max. 20.2\%), while in the sesquiterpene fraction the most abundant compounds were trans-caryophyllene (max. 18.6\%) and lavandulyl acetate (max. $18.1 \%)$. Among aromatic compounds, the most abundant was chamazulene (max. 29.1\%). Moreover, this screening has shown that only 10 populations out of 28 satisfied official quality requirement of $0.02 \%$ of chamazulene in the dried drug. Four populations $(1,19,20,24)$ had higher yield than commercial variety ProA (39), while one of them (20) had even higher level of chamazulene $(23.1 \%)$. These results favors cultivation of species with known chemical profile versus wildcrafting of morphologically very similar yarrow plants which do not satisfy quality requirements.

\section{ACKNOWLEDGMENTS}

Acknowledgment. This work was supported by the Ministry of Education, Science and Technological Development of the Republic of Serbia, project number 46013. The authors would like to thank Dragoja Radanović for providing seeds of population from Padej and Mariana Kostić for assistance in field measuring.

\section{REFERENCES}

Adams, R. P. (2007). Identification of Essential Oil Components by Gas Chromatography/mass Spectorscopy, Allured Publishing Corporation. Google-Books-ID: 9ut3PQAACAAJ.

Ali, S. I., Gopalakrishnan, B. and Venkatesalu, V. (2017). Pharmacognosy, Phytochemistry and Pharmacological Properties of Achillea millefolium L.: A Review, Phytotherapy Research 31(8): 1140-1161.

Benedek, B., Rothwangl-Wiltschnigg, K., Rozema, E., Gjoncaj, N., Reznicek, G., Jurenitsch, J., Kopp, B. and Glasl, S. (2008). Yarrow (Achillea millefolium L. s.l.): pharmaceutical quality of commercial samples, Die Pharmazie 63(1): 23-26.

Boskovic, Z., Radulovic, N. and Stojanovic, G. (2005). Essential Oil Composition of Four Achillea Species from the Balkans and Its Chemotaxonomic Significance, Chemistry of Natural Compounds 41(6): 674-678.

Cavalcanti, A. M., Baggio, C. H., Freitas, C. S., Rieck, L., de Sousa, R. S., Da Silva-Santos, J. E., Mesia-Vela, S. and Marques, M. C. A. (2006). Safety and antiulcer efficacy studies of Achillea millefolium L. after chronic treatment in Wistar rats, Journal of Ethnopharmacology 107(2): 277-284.
Chandler, R. F., Hooper, S. N. and Harvey, M. J. (1982). Ethnobotany and phytochemistry of yarrow, Achillea millefolium, compositae, Economic Botany 36(2): 203-223.

Conti, B., Canale, A., Bertoli, A., Gozzini, F. and Pistelli, L. (2010). Essential oil composition and larvicidal activity of six Mediterranean aromatic plants against the mosquito Aedes albopictus (Diptera: Culicidae), Parasitology Research 107(6): 1455-1461.

Dachler, M. and Pelzmann, H. (1999). Arznei- und Gewürzpflanzen: Anbau, Ernte, Aufbereitung, Österr. Agrarverl.

Gajić, M. (1975). Flora SR Srbije VII, SANU, chapter Genus Achillea, pp. 90-108.

Ghasemi Pirbalouti, A. (2017). Chemical Composition of the Essential Oils from the Leaves and Flowers of Two Achillea species from Iran, Journal of Essential Oil Bearing Plants 20(1): 205-214.

Giorgi, A., Bononi, M., Tateo, F. and Cocucci, M. (2005). Yarrow (Achillea millefolium L.) Growth at Different Altitudes in Central Italian Alps: Biomass Yield, Oil Content and Quality, Journal of Herbs, Spices $\mathcal{E}$ Medicinal Plants 11(3): 47-58.

Hochmuth, D. (2006). Massfinder 3: Software for GC/MS interpretation and presentation, mass spectral library administration. Hamburg, Germany.

Mockute, D. and Judzentiene, A. (2003). Variability of the essential oils composition of Achillea millefolium ssp. millefolium growing wild in Lithuania, Biochemical Systematics and Ecology 31(9): 1033-1045.

Nadim, M., Malik, A., Ahmad, J. and Bakshi, S. (2011). The Essential Oil Composition of Achillea millefolium L. Cultivated under Tropical Condition in India, World Journal of Agricultural Sciences 7: 561-565.

Nemeth, E. (2005). Essential Oil Composition of Species in the Genus Achillea, Journal of Essential Oil Research 17(5): 501512 .

Ph.Eur.8.0. (2013). European Pharmacopoeia 8.0, Council of Europe, Strasbourg.

Ph.Jug.IV (1951). Pharmacopoeia Jugoslavica, Vol. 2, Savezni zavod za zdravstvenu zaštitu, Belgrade, Serbia.

Raal, A., Orav, A. and Arak, E. (2012). Essential Oil Content and Composition in Commercial Achillea millefolium L. Herbs from Different Countries, Journal of Essential Oil Bearing Plants 15(1): 22-31.

Saukel, J. and Langer, R. (1992). Achillea millefolium-group (Asteraceae) in Mitteleuropa. 2. Populationsvergleich, multivariate analyse und biosystematische anmerkungen, Phyton 32(1): 47-78.

Shawl, A. S., Srivastava, S. K., Syamasundar, K. V., Tripathi, S. and Raina, V. K. (2002). Essential oil composition of Achillea millefolium L. growing wild in Kashmir, India, Flavour and Fragrance Journal 17(3): 165-168.

Spinarova, S. and Petrikova, K. (2003). Variability of the content and quality of some active substances within Achillea millefolium complex, Horticultural Science 30(1): 7-13.

Stojanović, G., Asakawa, Y., Palić, R. and Radulović, N. (2005). Composition and antimicrobial activity of Achillea clavennae and Achillea holosericea essential oils, Flavour and Fragrance Journal 20(1): 86-88. 
Tabanca, N., Ozek, T., Baser, K. H. C. and Vural, M. (2004). Composition of the Essential Oil of Achillea sieheana Stapf and the Enantiomeric Distribution of Camphor, Journal of Essential Oil Research 16(3): 180-181.

Tucakov, J. (1984). Lečenje biljem - Fitoterapija., Rad, Belgrade.

Verma, R. S., Joshi, N., Padalia, R. C., Goswami, P., Singh, V. R., Chauhan, A., Verma, S. K., Iqbal, H., Verma, R. K., Chanda, D., Sundaresan, V. and Darokar, M. P. (2017). Chemical composition and allelopathic, antibacterial, antifungal and in vitro acetylcholinesterase inhibitory activities of yarrow (Achillea millefolium L.) native to India, Industrial Crops and Products 104(Supplement C): 144-155.

Weyerstahl, P., Marschall, H., Seelmann, I. and Rustaiyan, A. (1997). Constituents of the Essential Oil of Achillea eriophora DC., Flavour and Fragrance Journal 12(2): 71-78.

Wichtl, M. (2004). Herbal Drugs and Phytopharmaceuticals: A Handbook for Practice on a Scientific Basis, 3rd edn, Medpharm Scientific Publishers, Stuttgart: Germany.

Willuhn, G. (2002). Teedrogen und Phytopharmaka, 4th edn, Wiss. Verlagsgesellschaft: Stuttgart, chapter Millefolii herba, p. 399-403. 